Jurnal Keperawatan Silampari

Volume 5, Nomor 1, Desember 2021

e-ISSN: 2581-1975

p-ISSN: 2597-7482

DOI: https://doi.org/10.31539/jks.v5i1.2109

\title{
PENGOBATAN ALTERNATIF BEKAM KERING TERHADAP KADAR KOLESTEROL DARAH
}

\author{
Syokumawena ${ }^{1}$, Marta Pastari ${ }^{2}$ \\ Politeknik Kesehatan Palembang ${ }^{1,2}$ \\ syokumawena@poltekkespalembang.ac.id ${ }^{1}$
}

\begin{abstract}
ABSTRAK
Tujuan penelitian ini adalah mengetahui efektifitas pengobatan alternatif bekam kering terhadap kadar kolesterol darah. Metode penelitian dalam penelitian ini menggunakan pre-eksperimen design, dengan rancangan yang digunakan two group pre and posttest design. Hasil penelitian menunjukkan sebagian besar kadar kolesterol darah sebelum dilakukan bekam adalah sebanyak 9 orang (30.0\%) dengan Kadar Kolesterol Darah Mengkhawatirkan (200-239). Sebagian besar kadar kolesterol darah sebelum dilakukan bekam 13 titik adalah 11 orang (36.7\%) dengan Kadar Kolesterol Darah Tinggi (>240), kemudian setelah bekam 13 titik sebanyak 11 orang (36.7\%) memiliki Kadar Kolesterol Darah Mengkhawatirkan (200-239). Simpulan, kelompok 9 dan 13 titik bekam memiliki pengaruh terhadap penurunan kadar kolesterol darah.
\end{abstract}

Kata Kunci: Bekam, Kolesterol, Pengobatan Alternatif

\section{ABSTRACT}

This study aimed to determine the effectiveness of dry cupping alternative treatment on blood cholesterol levels. The research method in this study used a pre-experimental design with a two-group pre-and post-test design. The results showed that most of the blood cholesterol levels before cupping were nine people (30.0\%) with worrying blood cholesterol levels (200-239). Most of the blood cholesterol levels before 13-point cupping were 11 people (36.7\%) with High Blood Cholesterol Levels (>240), then after 13-point cupping, 11 people (36.7\%) had Worrying Blood Cholesterol Levels (200-239). In conclusion, groups 9 and 13 cupping points affect reducing blood cholesterol levels.

Keywords: Cupping, Cholesterol, Alternative Medicine

\section{PENDAHULUAN}

Kolesterol merupakan lipid amfipatik yang penting dalam pengaturan permeabilitas dan fluiditas membran, dan juga sebagai lapisan luar lipoprotein plasma. Kolesterol merupakan gabungan senyawa steroid dan alkohol (atau yang dikenal dengan senyawa sterol) dan lemak yang ada pada membran sel di semua jaringan tubuh (Anggraini \& Nurvinanda, 2020). Kolesterol adalah sterol inilah yang paling dikenal oleh masyarakat. Terdapat dua jenis kolesterol yang diproduksi oleh tubuh, yaitu kolesterol baik atau High Density Lipoprotein (HDL) dan kolesterol jahat atau Low Density Lipoprotein (LDL) (Putri, 2019). Kedua jenis kolesterol ini memang dibutuhkan oleh tubuh, namun jika jumlah kadar kolesterol dalam darah berlebihan maka akan terjadi hiperkolesterolemia (Adhi, 2020). Hiperkolesterolemia adalah salah satu gangguan kadar lemak dalam darah 
(dislipidemia) yang mana kadar kolesterol dalam darah lebih dari $240 \mathrm{mg} / \mathrm{dL}$, sedangkan kadar normal kolesterol 150-200mg/dL (Ekayanti, 2019). Pengobatan hiperkolesterolemia tidak hanya dilakukan dengan metoda farmakologis saja, tetapi juga dapat dilakukan dengan cara non farmakologis. Salah satu pengobatan non farmakologis adalah dengan cara terapi bekam.

Pasien yang akan melakukan pengukuran lipid harus melakukan puasa dengan rekomendasi 12 jam pada waktu pengambilan sampel darah. Puasa dibutuhkan dikarenakan kadar trigliserida meningkat dan menurun secara dramatis pada keadaan post prandial dan nilai kolesterol LDL dihitung melalui perhitungan kolesterol serum total dan konsentrasi kolesterol HDL. Perhitungan ini berdasarkan sebuah rumus yang disebut Friedwald Equation, paling akurat untuk konsentrasi trigliserida dibawah 400 $\mathrm{mg} / \mathrm{dl}$. Tinggi kolesterol dalam darah adalah kondisi dimana terdapat banyak kolesterol di dalam darah. Semakin tinggi level kolesterol dalam darah, semakin besar risiko terjadinya Penyakit Jantung Koroner dan serangan jantung. Kadar lipid serum normal untuk seseorang belum tentu normal untuk orang lain yang disertai faktor risiko koroner. Kadar kolesterol darah dipengaruhi oleh masuknya makanan ke dalam tubuh (diet). Faktor-faktor lainnya yang dapat mempengaruhi kadar kolesterol darah di samping diet adalah keturunan umur dan jenis kelamin stress, alkohol dan exercise (Adhi, 2020). World Health Organisation (WHO) menyatakan, pengobatan tradisional adalah ilmu dan seni pengobatan berdasarkan himpunan dari pengetahuan dan pengalaman praktek, baik yang dapat diterangkan secara ilmiah maupun tidak, dalam melakukan diagnosis, prevensi dan pengobatan terhadap ketidakseimbangan fisik, mental ataupun sosial. Jenis pengobatan sekarang ini mengalami perkembangan yang cukup pesat dan peminatnya sangat banyak tersebar di Indonesia. Pengobatan jenis ini dibedakan dengan pengobatan alternatif lainnya, sebab memiliki akar sejarah perkembangan dari luar Indonesia.

Pengobatan alternatif atau terapi alternatif biasa disebut untuk menunjukkan pengobatan non-medis. Pengobatan alternatif juga disebut sebagai pengobatan tradisional. Pengobatan alternatif atau terapi alternatif merupakan bentuk pelayanan pengobatan yang menggunakan cara, alat atau bahan yang tidak termasuk dalam standar pengobatan kedokteran modern (pelayanan kedokteran standar) dan dipergunakan sebagai alternatif atau pelengkap pengobatan kedokteran modern tersebut (Zakaria et al., 2018). Bekam merupakan metode pengobatan dengan cara mengeluarkan darah yang terkontaminasi toksin atau oksidan dari dalam tubuh melalui permukaan kulit ari. Dalam istilah medis dikenal dengan istilah 'Oxidant Release Therapy' atau 'Oxidant Drainage Therapy' atau istilah yang lebih populer adalah 'detoksifikasi'. Bekam atau hijamah telah didemonstrasikan oleh Rasulullah SAW dan diajarkan kepada para sahabatnya (Siregar, 2020). Teknik pengobatan hijamah adalah suatu proses membuang darah kotor (toksid/racun) yang berbahaya dari dalam tubuh melalui bawah permukaan kulit (Norlita \& Wiradinata, 2020).

Ketua Umum Asosiasi Bekam Indonesia (ABI), Ahmad Fatahillah mengatakan bahwa bekam mulai dikenal di Indonesia sejak 1996 dan mendapat minat yang menggeliat dari masyarakat pada tahun 2000. Beberapa penelitian pendukung seperti penelitian Isnaniar et al., (2020) menunjukkan bahwa terapi bekam berpengaruh terhadap penurunan kadar kolesterol pada pasien hiperkolesterolemia. Hal ini sejalan dengan penelitian Siregar (2020) yang menemukan bahwa tradisi bekam dapat menurunkan tekanan darah pada pasien hipertensi. Penemuan lainnya juga menyatakan bahwa kadar kolesterol pada penderita hiperkolesterolemia dapat menurun dengan dilakukannya terapi bekam (Faizal et al., 2020). Sehingga, dapat dikatakan bahwa terapi 
bekam baik digunakan untuk terapi alternatif dalam mengontrol tekanan darah agar tetap stabil. Penelitian sebelumnya hanya meneliti tentang pengaruh bekam terhadap darah secara umum, namun penelitian ini berfokus pada kadar kolesterol dalam darah. Selain itu, belum banyak penelitian yang bertujuan secara khusus untuk melihat bagaimana keefektifan terapi bekam terhadap kadar kolesterol darah.

\section{METODE PENELITIAN}

Jenis penelitian yang digunakan adalah pre-eksperiment design dengan rancangan two group pre-posttest design. Perlakuan yang diberikan adalah dengan memberikan terapi bekam kering, sedangkan luaran (outcome) adalah perubahan profil lipid darah (catatan; bekam kering dilakukan oleh praktisi bekam Rumah Sehat Ibnu Sina, pengambilan sampel darah dilakukan oleh ahli teknologi laboratorium medik RSK Charitas Palembang. Penelitian ini dilakukan di Rumah Sehat Ibnu Sina Palembang. Pengambilan data penelitian dilakukan mulai 02 Oktober 2020 - 09 November 2020.

Populasi dalam penelitian ini adalah semua pengunjung tetap Rumah Sehat Ibnu Sina Palembang. Pengumpulan data dilakukan dengan cara; sebelum pengumpulan data, peneliti menjelaskan kepada calon responden tentang tujuan dan manfaat penelitian. Kemudian meminta persetujuan dari calon responden untuk menjadi responden dengan menandatangani lembar persetujuan informed consent. Kelompok responden, sebelum dan setelah dibekam dilakukan pemeriksaan kolesterol total darah.

Data hasil pengukuran selanjutnya dianalisis menggunakan software statistik. Pengolahan data dilakukan dengan bantuan komputer menggunakan software statistik SPSS for windows versi 17.0 dan dibantu program microsoft excel. Data yang terkumpul dalam penelitian ini dianalisis secara univariat dan bivariat.

\section{HASIL PENELITIAN}

Tabel. 1

Hasil Uji T Berpasangan Kelompok 9 Titik

\begin{tabular}{c|c|c|c}
\hline Kelompok & Sumber Data & $\begin{array}{c}\text { Wilcoxon Signed Ranks Test } \\
(\text { sig 2-Tailed })\end{array}$ & Keputusan \\
\hline 9 Titik & $\begin{array}{c}\text { Pre Test } \\
\text { Post Test }\end{array}$ & 0.000 & $\begin{array}{c}\text { Ada } \\
\text { Pengaruh }\end{array}$ \\
\hline
\end{tabular}

Berdasarkan tabel 1 terlihat bahwa hasil uji T berpasangan pada Kelompok 9 Titik adalah 0.000, karena nilai sig kurang dari nilai alpha (sig.<0.05). Maka untuk data kelompok 9 titik, dapat disimpulkan bahwa bekam memiliki pengaruh terhadap penurunan kadar kolesterol darah.

Tabel. 2

Hasil Uji T Berpasangan Kelompok 13 Titik

\begin{tabular}{c|c|c|c}
\hline Kelompok & Sumber Data & $\begin{array}{c}\text { Wilcoxon Signed Ranks Test } \\
(\text { sig 2-Tailed })\end{array}$ & Keputusan \\
\hline 13 Titik & $\begin{array}{c}\text { Pre Test } \\
\text { Post Test }\end{array}$ & 0.002 & $\begin{array}{c}\text { Ada } \\
\text { Pengaruh }\end{array}$ \\
\hline
\end{tabular}


Berdasarkan tabel 2 terlihat bahwa hasil uji T Berpasangan pada Kelompok 13 Titik adalah 0.002, karena nilai sig kurang dari nilai alpha (sig.<0.05). Maka untuk data kelompok 13 titik, dapat disimpulkan bahwa bekam memiliki pengaruh terhadap penurunan kadar kolesterol darah.

Kedua uji sudah dilakukan untuk kelompok 9 dan 13 titik. Hasil dari kedua pengujian pada masing masing kelompok adalah $\mathrm{H} 0$ ditolak dan $\mathrm{H} 1$ diterima, dengan simpulan akhir bahwa bekam 9 titik dan 13 titik memiliki pengaruh terhadap penurunan kolesterol.

Tabel. 3

Selisih Mean Titik Bekam

\begin{tabular}{|c|c|c|c|}
\hline \multirow[t]{2}{*}{ Kelompok } & \multicolumn{2}{|c|}{ Nilai rata-rata } & \multirow{2}{*}{$\begin{array}{c}\text { Selisih nilai rata-rata (pre } \\
\text { test - post test) }\end{array}$} \\
\hline & Pre Test & Post Test & \\
\hline 9 Titik & 188.93 & 183.77 & 5.16 \\
\hline 13 Titik & 224.60 & 207.77 & 16.83 \\
\hline
\end{tabular}

Berdasarkan tabel 3 terlihat bahwa terdapat besaran selisih mean, kelompok 13 titik jauh lebih besar daripada kelompok 9 titik. Hal ini dapat disimpulkan bahwa, dengan bekam 13 titik mampu menurunkan kolesterol lebih banyak jika dibandingkan dengan bekam 9 titik. Maka, bekam 13 titik lebih berpengaruh untuk menurunkan kolesterol jika dibandingkan dengan bekam 9 titik.

\section{PEMBAHASAN}

\section{Analisa Univariat}

\section{Kelompok 9 Titik (Perlakuan; Kadar Kolesterol Darah Sebelum Bekam Kering)}

Menunjukkan bahwa sebanyak 9 orang $(30,0 \%)$ dengan kadar kolesterol darah mengkhawatirkan (200-239). Hal ini didukung oleh penelitian Lutfiana et al., (2017) yang menunjukkan bahwa kadar kolesterol darah total subjek penelitian secara umum berkisar antara $226 \mathrm{mg} / \mathrm{dl}$ hingga $314 \mathrm{mg} / \mathrm{dl}$ sebelum bekam. Kadar ini cenderung menurun berdasarkan progres intervensi.

\section{Kelompok 9 Titik (Perlakuan; Kadar Kolesterol Darah Setelah Bekam Kering)}

Menunjukkan bahwa sebagian besar kadar kolesterol darah setelah dilakukan bekam 9 titik adalah sebanyak 8 orang $(30,0 \%)$ dengan kadar kolesterol darah yang mengkhawatirkan, terjadi penurunan jumlah walaupun tidak terlalu signifikan. Hal ini sejalan dengan penelitian Irafaizah (2019) yang menunjukkan kadar LDL sebelum dan sesudah terapi bekam pada pasien bekam di Dusun Bliming RT 008 RW 002 Desa Dawu Kecamatan Paron Kabupaten Ngawi, didapatkan hasil rata-rata sebelum bekam $96,82 \mathrm{mg} / \mathrm{dl}$ dan didapatkan hasil sesudah terapi bekam dengan rata- rata 94,19 mg/dl. Hasil juga menunjukkan penurunan kadar kolesterol darah secara signifikan setelah bekam.

\section{Kelompok 13 Titik (Perlakuan; Kadar Kolesterol Darah Sebelum Bekam Kering)}

Hasil penelitian menunjukkan sebagian besar kadar kolesterol darah sebelum dilakukan bekam 13 titik adalah 11 orang $(36,7 \%)$ dengan kadar kolesterol darah tinggi $(>240)$. 


\section{Kelompok 13 Titik (Perlakuan; Kadar Kolesterol Darah Sesudah Bekam Kering)}

Hasil penelitian menunjukkan sebanyak 11 orang $(36.7 \%)$ memiliki kadar kolesterol darah mengkhawatirkan (200-239). Rata-rata kadar kolesterol sampel pada penelitian ini adalah $228.86 \mathrm{mg} / \mathrm{dl}$, kadar kolesterol terendah adalah $120 \mathrm{mg} / \mathrm{dl}$ dan kadar kolesterol tertinggi adalah $596 \mathrm{mg} / \mathrm{dl}$ dan yang masuk dalam kadar kolesterol darah mengkhawatirkan sampai dengan tinggi.

Dari deskripsi hasil analisis univariat di atas, rata-rata pemeriksaan kadar kolesterol total dilakukan 20 menit setelah bekam, hal ini mengacu pada satuan pengukuran internasional yang mana setiap pemeriksaan dilakukan dalam rentang 15-20 menit setelah intervensi. Responden mengalami penurunan kadar kolesterol setelah terapi bekam dibuktikan dengan hasil uji t dependent didapatkan perbedaan nilai ratarata kadar kolesterol sebelum dan sesudah dilakukan terapi bekam (Faizal, 2019).

Kemudian menurut Lutfiana et al., (2017), kolesterol dalam darah ikut terangkat menuju kulit karena proses pembekaman; yang dapat diketahui bahwa mulai dilakukan terapi bekam kering terlebih dahulu tanpa adanya perlukaan, kemudian keadaan kulit mulai terangkat karena adanya tekanan, pada kop bekam.

\section{Analisis Bivariat}

Hasil uji $\mathrm{T}$ berpasangan pada kelompok 9 Titik adalah 0.000 , karena nilai sig kurang dari nilai alpha (sig.<0.05). Maka untuk data kelompok 9 titik, dapat disimpulkan bahwa bekam memiliki pengaruh terhadap penurunan kadar kolesterol darah. Selanjutnya pada Kelompok 13 Titik adalah 0.002, karena nilai sig kurang dari nilai alpha (sig.<0.05). Maka untuk data kelompok 13 titik, dapat disimpulkan bahwa bekam memiliki pengaruh terhadap penurunan kadar kolesterol darah. Kedua uji sudah dilakukan untuk kelompok 9 dan 13 titik. Hasil dari kedua pengujian pada masing masing kelompok adalah bekam 9 titik dan 13 titik memiliki pengaruh terhadap penurunan kolesterol.

Hasil penelitian ini diperkuat oleh Hidayat et al., (2018) yang mendapatkan bahwa terapi bekam dapat menurunkan kadar kolesterol pada pasien hiperkolesterol umur 45 tahun ke atas. Kemudian Muflih \& Judha (2019) menjelaskan bahwa variasi penurunan tekanan darah pada terapi bekam dapat ditentukan dari jumlah kop, durasi dan lokasi titik bekam. Hal ini sejalan dengan pernyataan semakin tinggi tekanan darah maka makin tinggi level kolesterol dalam darah, semakin besar pula resiko terjadinya Penyakit Jantung Koroner dan serangan jantung. Kadar lipid serum normal untuk seseorang belum tentu normal untuk orang lain yang disertai faktor risiko koroner.

Penyataan ini sejalan juga dengan penelitian Isnaniar et al., (2020) menunjukkan bahwa dari 53 orang responden yang mengalami hiperkolesterolemia, sebanyak 14 orang mengalami penurunan. Hasil uji statistik diperoleh hasil yang signifikan dengan $\mathrm{p}$ value $=0.000 \quad(\alpha<0.05)$, sehingga disimpulkan bahwa terapi bekam berpengaruh terhadap penurunan kadar kolesterol dalam darah pada pasien hiperkolesterolemia. Selanjutnya Suwarsi (2019) mendapatkan juga bahwa kadar kolesterol darah lansia pada kelompok intervensi setelah dilakukan terapi bekam rata-rata mengalami penurunan $42.89 \mathrm{mg} / \mathrm{dl}$, sedangkan untuk kadar kolesterol darah pada kelompok kontrol mengalami penurunan rata-rata $20.95 \mathrm{mg} / \mathrm{dl}$. Seluruh hasil penelitian di atas didukung oleh teoriteori Lutfiana et al., (2017), yang dinyatakan dalam gambar di bawah ini; 


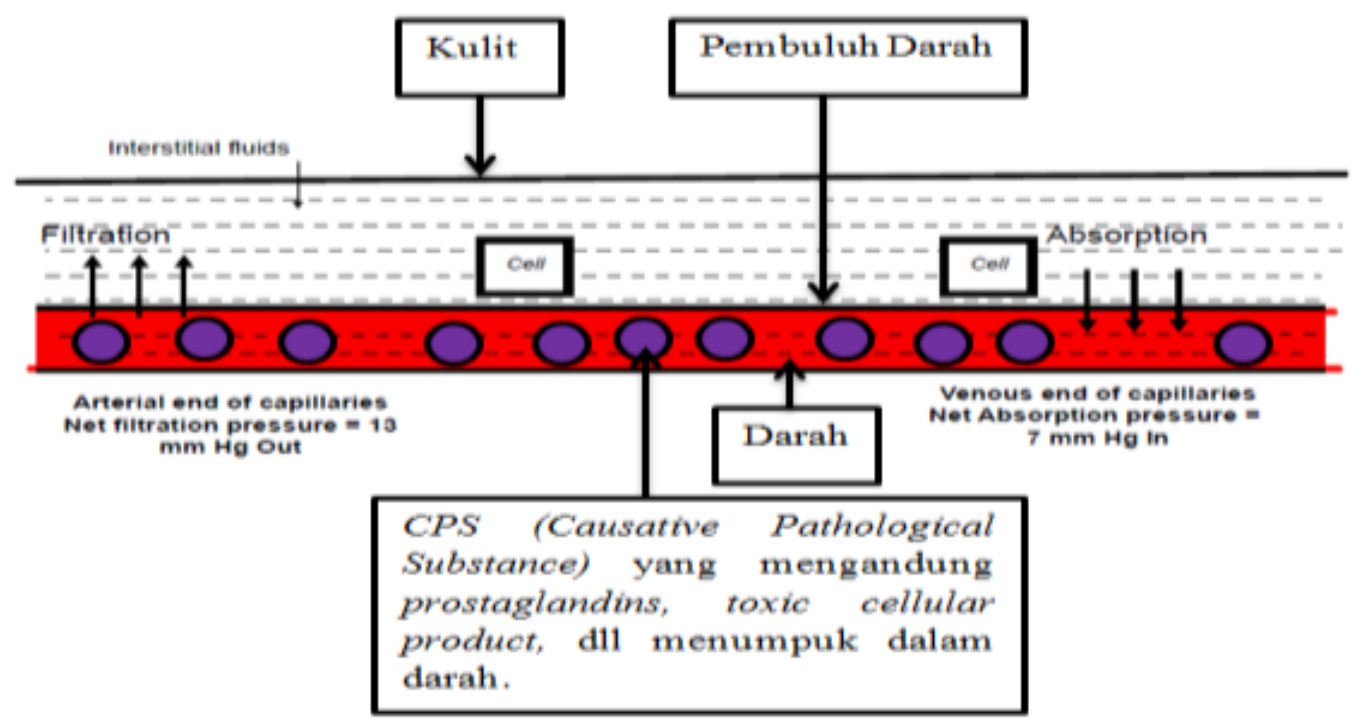

Gambar. 1

Penumpukan Kolesterol di Dalam Darah

Pada gambar 1 di atas dapat diketahui keadaan kulit dan pembuluh darah sebelum dilakukan terapi bekam. Didalam pembuluh darah terdapat banyak sampah metabolisme yang disebut CPS (Causative Pathological Substance) salah satunya kolesterol. Kemudian setelah dilakukan bekam kering maka yang terjadi adalah;

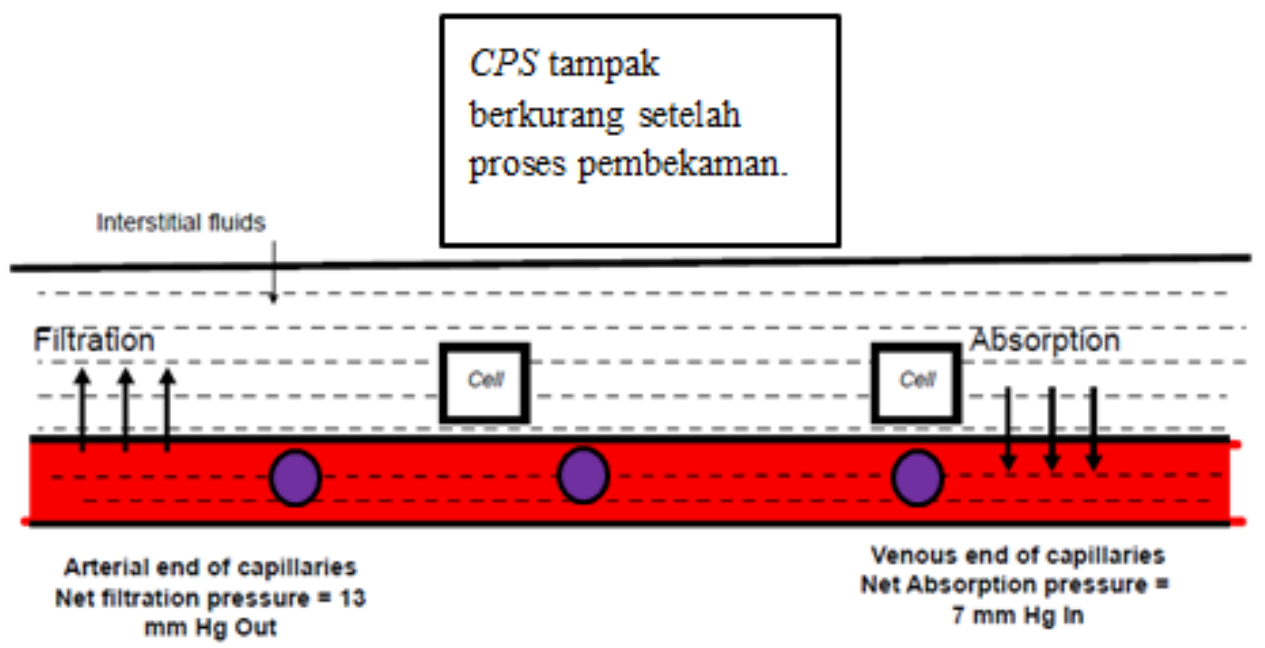

Gambar. 2

Keadaan Pembuluh Darah Setelah Bekam Kering

Pada gambar 2 di atas dapat diketahui bahwa keadaan kulit setelah proses pembekaman. Bila dibandingkan dengan gambar 1 dapat terlihat pada gambar 2 kandungan kolesterol dalam darah tampak berkurang. Kesimpulan yang dapat diambil adalah bahwa terapi bekam efektif terhadap kadar kolesterol pada penderita hiperkolesterolemia. 
Analisis bivariat lainnya dilakukan pengujian selisih mean untuk mengetahui titik bekam manakah yang memiliki pengaruh lebih besar dalam menurunkan kadar kolesterol darah. Kemudian didapatkan hasil bahwa bekam 13 titik mampu menurunkan kolesterol lebih banyak jika dibandingkan dengan bekam 9 titik. Maka, bekam 13 titik lebih berpengaruh untuk menurunkan kolesterol jika dibandingkan dengan bekam 9 titik.

Hal ini sejalan dengan El-Ghaffaar et al., (2020) yang menyatakan bahwa cupping therapy has favorable effects on reducing total cholesterol and LDL-C serum levels as well as increasing HDL-C serum levels. Hasil penelitian lainnya yaitu oleh Arozi (2018) didapatkan bahwa hasil analisis bivariat menggunakan T-Test menunjukkan bahwa ada pengaruh yang signifikan antara terapi bekam terhadap kadar kolesterol total pada pasien hiperkolesterolemia dengan $\mathrm{p}$ value $0.000<0.05$.

Hal ini diperkuat oleh Al-Khaleda (2018) yang menyatakan pada dasarnya titiktitik bekam juga merupakan perpaduan titik meridian akupuntur. Titik-titik bekam ini bermanfaat untuk pencegahan dan penyembuhan penyakit, adapun mengenai titik bekam, tedapat perbedaan pendapat. Salah satunya ada yang berpendapat bahwa bekam memiliki 98 titik, 55 titik diantaranya di bagian punggung, dan 43 titik di wajah dan perut. Setiap penyakit memiliki titik bekam tertentu pada tubuh manusia. Banyaknya titik bekam ini tak lain karena fungsi dan pengaruh-pengaruhnya pada tubuh. Titik yang dianggap paling penting yang menjadi titik bersama seluruh penyakit dan menjadi titik awal bekam adalah punggung bagian atau sejajar dengan pundak dan di bawah tengkuk, karena titik tersebut merupakan tempat berkumpulnya darah kotor.

\section{SIMPULAN}

Kelompok 9 dan 13 titik bekam memiliki pengaruh terhadap penurunan kadar kolesterol darah. Namun, berdasarkan besaran selisih mean, kelompok 13 titik jauh lebih besar daripada kelompok 9 titik sehingga bekam 13 titik lebih berpengaruh untuk menurunkan kolesterol dibandingkan dengan bekam 9 titik.

\section{SARAN}

Untuk peneliti selanjutnya, diharapkan lebih memperhatikan jeda waktu dan faktor-faktor perancu saat proses pembekaman dan pengambilan yang secara nyata dapat mempengaruhi hasil penelitian. Peneliti selanjutnya juga dapat menggunakan interval pemberian secara berkala serta memodifikasi intervensi berdasarkan manfaat terhadap kadar kolesterol darah.

\section{DAFTAR PUSTAKA}

Adhi, I. S. (2020). 8 Tanda Kolesterol Tinggi yang Sering Tak Disadari. Kompas.Com. https://health.kompas.com/read/2020/07/31/120000768/8-tanda-kolesterol-tinggiyang-sering-tak-disadari?page $=$ all

Al-Khaleda, S. (2018). Terapi Hijamah (Bekam) Menurut Pendekatan Sejarah dan Sunnah. Universitas Islam Negeri Sumatera Utara. http://repository.uinsu.ac.id/4223/1/TESIS\%20CD\%20SYAFIYA.pdf

Anggraini, R. B., \& Nurvinanda, R. (2020). Skrining Kesehatan tentang Hipertensi, Kolestrol dan Diabetes Militus di Desa Cengkong Abang Kabupaten Bangka. Jurnal Kreativitas Pengabdian Kepada Masyarakat (PKM), 3(2), 346-351. http://ejurnalmalahayati.ac.id/index.php/kreativitas/article/view/2897 
Arozi, E. Z. A. (2018). Pengaruh Terapi Bekam terhadap Kadar Kolesterol Total pada Pasien Hiperkolesterolemia di Klinik Pengobatan Islami Refleksi dan Bekam Samarinda. Universitas Muhammadiyah Kalimantan Timur. http://idspace.umkt.ac.id/handle/ 463. 2017/618

Ekayanti, I. G. A. S. (2019). Analisis Kadar Kolesterol Total dalam Darah Pasien dengan Diagnosis Penyakit Kardiovaskuler. International Journal of Applied Chemistry Research, 1(1), 6-11. https://doi.org/10.23887/ijacr-undiksha

El-Ghaffaar, H. A. A., Mandour, J. K., \& Atia, F. A. E. (2020). Response of Cholesterol to Cupping Therapy in Post-Menopausal Women with Hypercholesterolemia. EurAsian Journal of BioSciences, 14(1), 123-127. http://www.ejobios.org/article/response-of-cholesterol-to-cupping-therapy-inpost-menopausal-women-with-hypercholesterolemia-8547

Faizah, H. I. (2019). Gambaran Kadar Kolesterol LDL Sebelum dan Sesudah Terapi Bekam pada Pasien Terapi Bekam Studi di Dusun Blimbing RT 008 RW 002 Desa Dawu Kecamatan Paron Kabupaten Ngawi. STIKES Insan Cendekia Medika. http://repo.stikesicme-jbg.ac.id/2731/

Faizal, M. (2019). Pengaruh Terapi Bekam terhadap Kadar Kolesterol di Rumah Sakit Bakti Timah Pangkal Pinang. Psikologi Perkembangan, 2(10), 1-224

Faizal, M., Nurvinanda, R., \& Zupera, Z. (2020). Pengaruh Terapi Bekam terhadap Kadar Kolesterol di Rumah Sakit Bakti Timah Pangkalpinang. Manuju: Malahayati Nursing Journal, 2(2), 259-267. https://doi.org/https://doi.org/10.33024/manuju.v2i2.2375

Hidayat, S. A., Anggeraini, S., Hidayat, T. Q., \& Malli, R. (2018). Pengaruh Terapi Bekam terhadap Penurunan Kadar Kolesterol pada Pasien Hypercholesterolemia di Rumah Sehat Al-Hijamaah Tahun 2014/2015. Al-Iqra Medical Journal: Jurnal Berkala Ilmiah Kedokteran, 1(1), 41-47. DOI: 10.26618/aimj.v1i1.2769

Isnaniar, Norlita, W., \& Wiradinata, D. I. (2020). Pengaruh Terapi Bekam terhadap Kadar Kolesterol Pasien Hiperkolesterolemia di Thibbun Nabawi Centre RSIA Zainab Pekanbaru Tahun 2019. Photon: Jurnal Sain Dan Kesehatan, 10(2), 1-12. https://doi.org/10.37859/jp.v10i2.1869

Lutfiana, A., Widada, W., \& Sasmito, G. (2017). Efektifitas Terapi Bekam terhadap Kadar Kolesterol pada Penderita Hiperkolesterolemia di UPT Pelayanan Sosial Tresna Werdha Jember. Universitas Muhammadiyah Jember. http://repository.unmuhjember.ac.id/978/1/ARTIKEL.pdf

Muflih, M., \& Judha, M. (2019). Effectiveness of Blood Pressure Reduction Reviewed from Amount of Kop, Duration and Location of Point of Bekam Therapy. NurseLine Journal. https://doi.org/10.19184/nlj.v4i1.9042

Norlita, W., \& Wiradinata, D. I. (2020). Pengaruh Terapi Bekam terhadap Kadar Kolesterol Pasien Hiperkolesterolemia di Thibbun Nabawi Centre RSIA Zainab Pekanbaru Tahun 2019. Photon: Jurnal Sains dan Kesehatan, 10(2), 125-136. DOI: 10.37859/jp.v10i2.1869

Putri, A. (2019). Hubungan Kadar LDL Kolesterol dengan Asam Urat pada Laki-laki Penderita Artrhitis Urika di RSU Mayjen H.A Thalib Kerinci. Sekolah Tinggi Ilmu Kesehatan Perintis Padang. http://repo.stikesperintis.ac.id/284/1/Skripsi\%20annisya\%20putri-dikonversi.pdf

Siregar, M. (2020). Efektivitas Terapi Bekam dalam Menurunkan Tekanan Darah pada Pasien Hipertensi di Indonesia: Sistematic Review. Jurnal Implementasi Husada, 1(3). https://doi.org/https://doi.org/10.30596/jih.v1i3.5672 
Suwarsi, S. (2019). Intervensi Keperawatan dalam Penurunan Kadar Kolesterol Darah dan Tekanan Darah pada Kelompok Lansia yang Diberikan Cupping Therapy di Desa Wedomartani Sleman. Jurnal Keperawatan Respati Yogyakarta. https://doi.org/10.35842/jkry.v6i1.299

Zakaria, M. M., Mahzuni, D., \& Septiani, A. (2018). Implementasi Pengobatan Alternatif sebagai Bentuk Kearifan Lokal pada Masyarakat Desa Mekargalih Kecamatan Jatinagor Kabupaten Sumedang. Dhamakarya: Jurnal Aplikasi Ipteks untuk Masyarakat, 8(1), 46-52. http://jurnal.unpad.ac.id/pkm/article/view/20252 